\title{
Analysis of Baby Stunting Prevalence Causing Factors in the Pandemy Era COVID-19
}

\author{
Harapan Parlindungan Ringoringo ${ }^{1 *}$, Qomariyatus Sholihah², Dike Maharany ${ }^{3}$, Wahyudi Kuncoro ${ }^{4}$, Imam Luthfansa ${ }^{4}$, \\ Kumoro Asto Lenggono ${ }^{5}$ \\ ${ }^{1}$ Faculty of Medicine, Lambung Mangkurat University, Banjarmasin, Indonesia; ${ }^{2}$ Deprtment of Industrial, Faculty of Engineering, \\ Brawijaya University, Malang, Indonesia; ${ }^{3}$ Public Health Office, Gresik, East Java, Indonesia; ${ }^{4}$ Department of Medical, Student \\ the MMRS, Brawijaya University, Malang, Indonesia; ${ }^{5}$ Lecture and Doctoral Program of Environmental Studies, Brawijaya \\ University, Malang, Indonesia
}

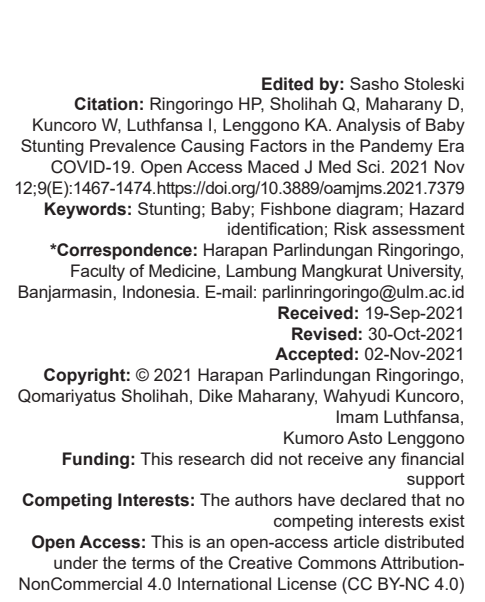

Abstract

AIM: The research objectives are to analyze prevalence factors stunting of a baby during the COVID-19 pandemic. The prevalence rate of stunting under five in Indonesia is high due to the lack of awareness and knowledge of the community. This could prevent the government from fulfilling the need for quality human resources in the future.

METHODS: This study is an analytical descriptive study that aims to explain the factors that cause the prevalence of stunting under five in the era of the COVID-19 pandemic. Data analysis using fishbone diagrams, hazard identification, and risk assessment of the six factors.

RESULTS: Furthermore, the analysis was carried out using hazard identification and risk assessment and obtained several risk categories, namely low risk of $13.3 \%$, moderate $40 \%$, high by $20 \%$, and extreme by $26.7 \%$.

CONCLUSION: The recommendations for improvement given refer to the extreme category because it is felt that this category has the highest urgency. The recommendations given are expected to assist the government in achieving the target of reducing the prevalence rate of stunting under five in Indonesia.

\section{Introduction}

The National Medium-Term Development Plan (RPJMN) in 2019-2024 is a priority that can support development and development that makes human resources in Indonesia become competitive and quality human resources, so that the existence of these human resources can help inclusive and equitable development in Indonesia [1]. The need for quality human resources is an important factor so that targets and targets must be met, especially in the health sector, and can influence the factor of reducing the prevalence of stunting in Indonesia to create a quality human resource. This problem has become a particular problem for the Indonesian government. The formation of the National Strategy for the Acceleration of Stunting Reduction in Indonesia by the government and coordinated directly by the vice president involves all public entities in Indonesia so that this is no longer a mere stunting problem, but the government has also determined that in 2024 the stunting reduction rate can be $14 \%$ and Bappenas is also targeting to be $19 \%$ [2].
The $65^{\text {th }}$ World Health Assembly set a target that by the year 2025, the stunting prevalence of children under 5 years should be mitigated by $50 \%$ as compared with the baseline in 2010 established by the World Health Organization (WHO) [3]. Globally, approximately 171 million children under the age of 5 years had some sort of stunting that affected their development [4]. Previous studies have shown that the stunting prevalence inequality among different populations is attributed to social, economic, and political determinants [5].

Stunting affected an estimated $22.9 \%$ or 154.8 million children under five globally in 2016 and on two continents; Asia and Africa are home to the majority of children who are stunted and each of them contributes 87 million and 59 million to the burden of stunting among children in the world (FAO, 2017). According to the $\mathrm{WHO}$, a child is said to be stunted if the height for age is below minus 2 standard deviations from the median WHO Child Growth Standard. Hence, stunting is a condition of failure to thrive in children under five due to chronic malnutrition so that the child is too short for his age. Child undernutrition has long-term 
negative consequences. An undernourished child will have repeated episodes of infection, be less competent in his education, and lower productivity than a wellnourished child and there is significant concern that COVID-19 responses have hurt the nutritional status of women and children, and that these could worsen over time [6], [7], [8]. Based on the results of research conducted by Langley-Evans, (2004), the dominant factors causing stunting are recurrent disease, wrong choice of daily food intake, and problems in growth hormone; while heredity only has a contribution value of $15 \%$ to the causes of stunting.

Stunting has an impact on the short and longterm. The short-term impact can affect the decrease in the child's immune system so that it is susceptible to disease, while the long-term impact is that it can affect the decline in children's motor and cognitive development [9]. This will greatly affect the quality of human resources in the future in Indonesia so that with this situation the government should be able to invest in improving the quality of public nutrition. Based on a research report by the Global Nutrition Report and the Copenhagen Consensus in 2014 that an investment of 1 Dollar in nutrition can generate 30 Dollars in improving health, education, and productivity-related to the economy, an investment in improving nutrition can reduce the poverty chain and increase the country's PDF up to $3 \%$ in 1 year [10]. The existence of this report also says that 1 dollar spent in reducing stunting rates through specific interventions with a minimum coverage of $90 \%$ can help as much as 48 dollars so that with developing countries allocating 100 dollars for the provision of micronutrients, additional food, deworming and diarrhea, can reduce chronic nutritional problems by up to $36 \%$ [11].

The United Nations (UN) in July 2020 said that the social and economic crisis caused by the COVID-19 virus pandemic could potentially cause nearly $7,000,000$ children to be stunted due to malnutrition and consequently 180,000 children could die. Before the COVID-19, it was estimated that $47,000,000$ children under five experienced moderate to severe wasting and this mostly occurred in Saharan Africa and Southeast Asia [12].

The prevalence of stunting of infants and children under 5 years of age (toddlers) in Indonesia in 2015 was $36.4 \%$. This means that more than a third or around 8.8 million children under five have nutritional problems where their height is below the standard according to their age [13]. The stunting rate is above the WHO threshold of $20 \%$ [14]. The prevalence value of stunting under five in Indonesia is the second largest in the Southeast Asia region and is below the country of Laos, which reached $43.8 \%$. However, based on the Nutritional Status Monitoring (PSG) 2017, under five who experienced stunting was recorded at $26.6 \%$. This figure is a division of $9.8 \%$ which is included in the very short category and $16.8 \%$ is included in the short category. The first 1000 days of toddlers are a very good age for toddlers, but, at that age, there are still many who experience nutritional problems. Hence, to suppress this problem, the government created a work program to prevent stunting by collaborating with multisector partnerships. TNP2K carried out its program in 160 districts which have become priorities for reducing stunting. In 2018 the Indonesian Ministry of Health again carried out Basic Health Research (Riskesdas) conducted by the Health Research and Development Agency (Litbangkes) on Stunting Prevalence. Based on this study, the number of stunting or children growing short fell from 37.2 percent in Riskesdas 2013 to 30.8 (TNP2K, 2018). The following is the data on the prevalence of stunting under five in Indonesia in 20132019 (Figure 1).

COVID-19 is a disease caused by the SarsCov-2 virus which mainly attacks the respiratory tract. Direct transmission is through saliva droplets of COVID-19 sufferers when they talk, cough or sneeze. Indirectly, the transmission can be through objects or surfaces that have been contaminated by the saliva of people with COVID-19 (WHO, 2020). The transmission of COVID-19 that has occurred in several countries has caused a decline in several aspects. Workers, employers, and organizations face major challenges in fighting the COVID-19 pandemic and are required to create safety and health protection in the workplace concerned. The risk of occupational safety and health $(\mathrm{OSH})$ in the workplace has also increased due to the spread of COVID-19 prevention and control measures are needed to overcome the risk of spread, OSH risk, and psychosocial risk.

The COVID-19 pandemic adds to the risk of possibly increasing the number of stunting. So that with this, the prediction of reducing the stunting rate in Indonesia to $14 \%$ is deemed difficult to achieve. One of the supporting factors is that many Posyandu is no longer operating as well as health workers who have also been affected by the existence of COVID-19. Measures in monitoring or controlling forms on a routine basis during growth in health facilities are very important to prevent the occurrence of malnutrition in children. If the process of measuring body weight, body length, and head circumference is not carried out quickly, it will cause chronic malnutrition and can lead to stunting. For the number of people suffering from stunting to decrease, it is necessary to modify a government policy strategy that can be implemented in all regions in Indonesia.

\section{Methods}

This research was a descriptive-analytic study, which takes place in Malang. Descriptive research aims to find an explanation or fact of an event that is happening [15]. The time for data collection was carried 
out from October 2020 to December 2020. The data collection process was carried out by studying literature studies and conducting interviews. Furthermore, data processing was carried out by linking the results of interviews related to policies, applicable guidelines, and laws and regulations.

This research was conducted using the Hazard Identification and Risk Assessment (HIRA) method of each factor that causes the prevalence of stunting. To obtain HIRA-related data, questionnaires were distributed randomly to obtain samples. The questionnaire given can be seen in Appendix 1. Hazard Identification is obtained through analysis using Fishbone Diagram. Furthermore, a risk assessment will be carried out by weighting each factor that causes the prevalence of stunting. After the weighting is obtained, a risk assessment diagram will be made to see the distribution of the overall weighting. After making the diagram, the author will provide several recommendations for factors classified into extreme and high and provide several recommendations for improvement and prevention both preventive, curative, and promotive actions.

Risk assessment was a risk assessment based on the causes and consequences of the resulting risk. Risk assessment is carried out using Australian and New Zealand standardization or better known as AS/ NZS 4360. There were 3 things discussed in it, namely severity, likelihood (frequency of occurrence), and risk matrix. The likelihood scale can be seen in Table 1.

Table 1: Likelihood Scale at US / NZS Standard 4360: 2004

\begin{tabular}{lll}
\hline Scale & Criteria & Details \\
\hline 1 & Rare & Can occur in certain circumstances \\
2 & Unlikely & Sometimes it happens \\
3 & Occasionally & The risk may occur but is infrequent \\
4 & Likely & Occurred several times in a certain period \\
5 & Almost certain & Can occur at any time under normal conditions \\
\hline Source: AS/NZS & 4360 Standard. &
\end{tabular}

Next is the severity scale on the AS/NZS 4360: 2004 standard which is used to determine the severity level associated with the potential for accidents to occur [16]. The severity scale on the AS/NZS 4360: 2004 standard is shown in Table 2.

Table 2: The scale of Severity in AS / NZS 4360: 2004 Standard

\begin{tabular}{|c|c|c|c|}
\hline \multirow[t]{2}{*}{ Scale } & \multirow[t]{2}{*}{ Criteria } & \multicolumn{2}{|l|}{ Description } \\
\hline & & Severity & Weekday Injury \\
\hline 1 & Insignificant & $\begin{array}{l}\text { The incident did not cause harm or injury } \\
\text { to humans }\end{array}$ & $\begin{array}{l}\text { Does not cause lost } \\
\text { workdays }\end{array}$ \\
\hline 2 & Minor & Causes minor injury or loss & $\begin{array}{l}\text { Causes minor injury } \\
\text { or loss }\end{array}$ \\
\hline 3 & Moderate & $\begin{array}{l}\text { The injuries are serious and can be } \\
\text { treated at home }\end{array}$ & $\begin{array}{l}\text { The injuries are serious } \\
\text { and can be treated at } \\
\text { home }\end{array}$ \\
\hline 4 & Major & $\begin{array}{l}\text { Can cause serious injury and permanent } \\
\text { disability as well as large financial losses } \\
\text { and can have a serious impact on } \\
\text { business continuity }\end{array}$ & $\begin{array}{l}\text { Can lose } 3 \text { or more } \\
\text { working days }\end{array}$ \\
\hline 5 & Catastrophic & $\begin{array}{l}\text { It can result in the victim's death and } \\
\text { serious losses and it can even stop } \\
\text { business activities forever }\end{array}$ & Lost workdays forever \\
\hline
\end{tabular}

Further in determining the risk assessment matrix is done by combining the likelihood scale and severity scale. The risk assessment matrix can be seen in Table 3.
Table 3: Risk Assessment Matrix in AS / NZS 4360: 2004 Standard

\begin{tabular}{llllll}
\hline Likelihood of the & & Occurrence Reasonable Severity & & \\
\cline { 2 - 6 } Severity & (1) insignificant & (2) Minor & (3) Moderate & (4) Major & (5) Catastrophic \\
\hline (5) almost & High & High & Extreme & Extreme & Extreme \\
certain & & & & & \\
(4) likely & Moderate & High & High & Extreme & Extreme \\
(3) occasionally & Low & Moderate & High & Extreme & Extreme \\
(2) unlikely & Low & Low & Moderate & High & Extreme \\
(1) rare & Low & Low & Moderate & High & High \\
\hline Source:AS/NZS 4360 Standard & & & &
\end{tabular}

Source: AS/NZS 4360 Standard.

\section{Results}

The results of the research provided are related to the results of the analysis using the fishbone diagram, hazard identification, and risk assessment of the six factors in the fishbone diagram related to the factors causing the high prevalence rate of stunting under five in Indonesia.

\section{Fishbone diagram}

The following is a fishbone diagram analysis of the factors that cause the high value of child stunting in Indonesia. Analysis using the fishbone diagram refers to the 6 fishbone diagram factors, namely man, machine, method, money, material, and environment. Fishbone diagram analysis can be seen in Figure 2.

\section{Hazard identification}

The following is a hazard identification analysis of the factors causing the high value of child stunting in Indonesia that has been obtained from the analysis using a Fishbone diagram. Hazard identification can be seen in Table 4.

Table 4: Stunting hazard identification

\begin{tabular}{lll}
\hline Activity & Hazard & Risk \\
\hline Stunting & Man & Lack of implementation of PHBS \\
& Lack of health education for health workers \\
& The low coverage of exclusive breastfeeding \\
& Lack of baby nutrition \\
& The education of the mother is low \\
& Transportation of cadres who are less supportive \\
& Lack of counseling related to infant nutrition \\
Machine & Lack of counseling related to exclusive breastfeeding \\
Methode & Counseling less attractive \\
& The minimum salary of cadres \\
& Lowey family economy & Lack of availability of the right tools \\
& Material & Poor sanitation and water supply \\
Environment & Lack of family support \\
& The toilet is not hygienic \\
\hline
\end{tabular}

\section{Risk assessment}

The following is a risk assessment analysis based on the results of the hazard identification analysis, which is related to the prevalence of stunting under five in Indonesia. Grading is done by adjusting the literature study and the results of distributing questionnaires to 
respondents. Risk assessment refers to the factors in the fishbone diagram, namely man, machine, method, money, material, and environment.

\section{Man factor risk assessment}

The following is a risk assessment analysis of the man factors that have been obtained from the results of hazard identification. Man factor risk assessment can be seen in Table 5 .

Table 5: Risk assessment of man factors

\begin{tabular}{lllll}
\hline Hazard & Risk & S & L & R \\
\hline Man & Lack of implementation of PHBS & 3 & 5 & Extreme \\
& Lack of health education for health workers & 3 & 2 & Moderate \\
& The low coverage of exclusive breastfeeding & 5 & 2 & Extreme \\
& Lack of baby nutrition & 4 & 4 & Extreme \\
& The education of the mother is low & 2 & 2 & Low \\
\hline Source: Primary Data (2020). & & &
\end{tabular}

Theresults oftheanalysiswith the riskassessment of the man factor obtained several risk categories about the severity and likelihood values, namely the lack of implementation of PHBS given a severity value of 3 and a likelihood value of 5 so that it is included in the extreme risk category. The lack of counseling for health workers is given a severity score of 3 and a likelihood value of 2 so that it is included in the moderate risk category. The low coverage of exclusive breastfeeding is given a severity value of 5 and a likelihood value of 2 so that it is included in the extreme risk category. Inadequate nutritional intake of infants is given a severity score of 4 and a likelihood of 4 so it is included in the extreme risk category. The low level of maternal education is given a severity score of 2 and a likelihood value of 2 so that it is included in the low-risk category.

\section{Machine factor risk assessment}

The following is a risk assessment analysis of the machine factors that have been obtained from the results of hazard identification. Machine factor risk assessment can be seen in Table 6 .

Table 6: Risk assessment factor machine

\begin{tabular}{lllll}
\hline Hazard & Risk & S & L & R \\
\hline Machine & Transportation of cadres who are less supportive & 2 & 3 & Moderate \\
\hline Source: Primary Data (2020). & & &
\end{tabular}

The results of the analysis with a risk assessment of the machine factor show that the transportation of cadres that is less supportive is given a severity score of 2 and a likelihood value of 3 so that it is included in the moderate risk category.

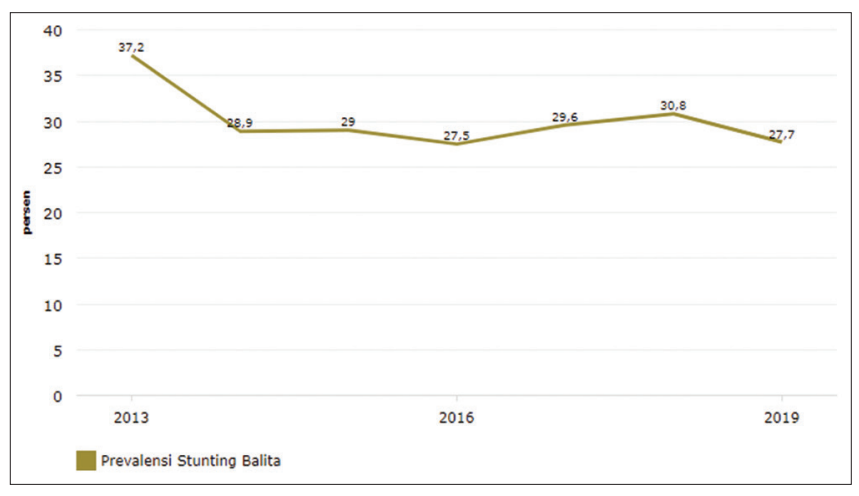

Figure 1: Prevalence Data of Toddler Stunting in Indonesia, 2013 2019. Source: Kemenkes (2020)

\section{Methode factor risk assessment}

The following is a risk assessment analysis of the method factors that have been obtained from the results of hazard identification. The risk assessment factor method can be seen in Table 7 .

\section{Table 7: Risk assessment factor method}

\begin{tabular}{lllll}
\hline Hazard & Risk & S & L & R \\
\hline Methode & Lack of counseling related to infant nutrition & 3 & 2 & Moderate \\
& Lack of counseling related to exclusive breastfeeding & 4 & 2 & High \\
& Counseling less attractive & 3 & 2 & Moderate \\
\hline Source: Primary Data (2020). & & &
\end{tabular}

The results of the analysis with the risk assessment of the method factor showed that the lack of

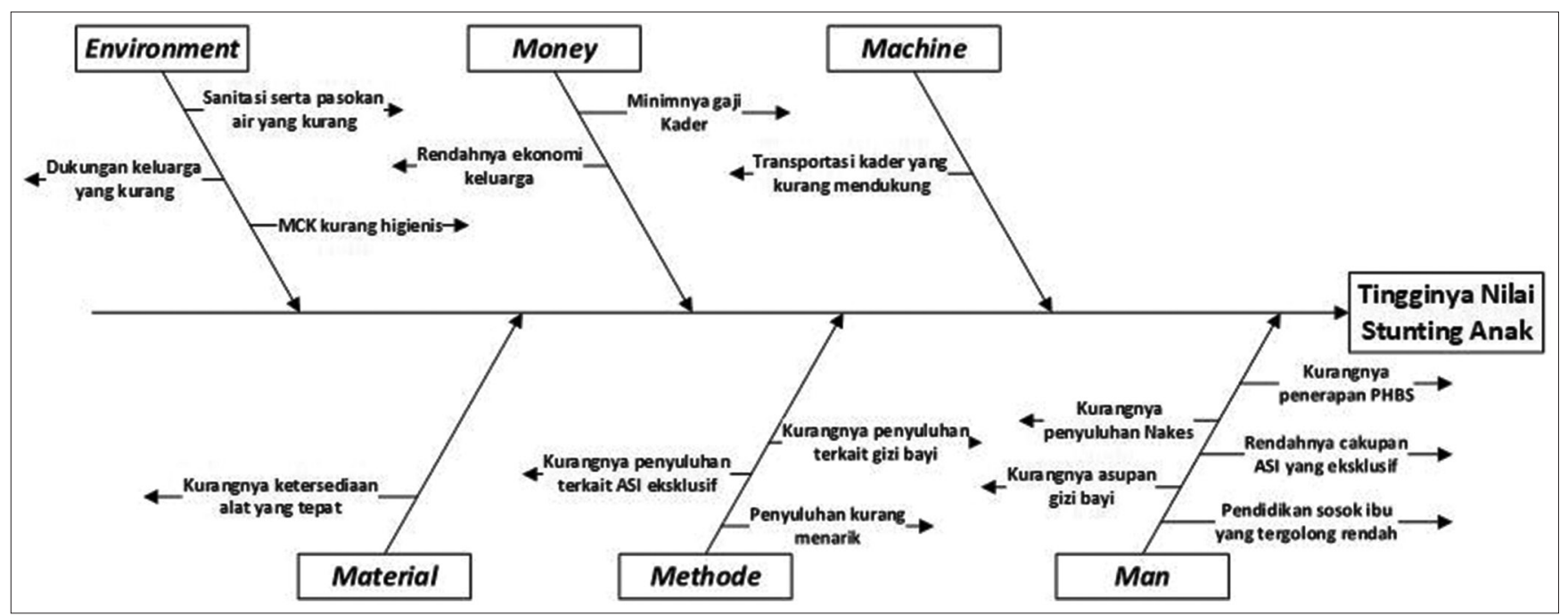

Figure 2: Fishbone Diagram of the High Value of Child Stunting. Source: Primary Data (2020) 
counseling related to infant nutrition was given a severity value of 3 and a likelihood value of 2 so that it was included in the moderate risk category. Lack of counseling related to exclusive breastfeeding is given a severity score of 4 and a likelihood value of 2 so that it is included in the high-risk category. Less attractive counseling was given a severity score of 3 and a likelihood value of 2 so that it was included in the moderate risk category.

\section{Money factor risk assessment}

The following is a risk assessment analysis of the money factor that has been obtained from the results of hazard identification. The risk assessment of the money factor can be seen in Table 8.

Table 8: Risk assessment of money factors

\begin{tabular}{lllll}
\hline Hazard & Risk & S & L & R \\
\hline Money & The minimum salary of cadres & 2 & 2 & Low \\
& Low family economy & 4 & 4 & Extreme \\
\hline Source: Primary Data (2020). & & &
\end{tabular}

The results of the analysis with a risk assessment of the money factor show that the minimum salary of cadres is given a severity value of 2 and a likelihood value of 2 so that it is included in the low-risk category. The low family economy is given a severity score of 4 and a likelihood value of 4 so that it is included in the moderate risk category.

\section{Material factor risk assessment}

The following is a risk assessment analysis of material factors that have been obtained from the results of hazard identification. Material risk assessment factors can be seen in Table 9.

Table 9: Risk assessment of material factors

\begin{tabular}{lllll}
\hline Hazard & Risk & S & L & R \\
\hline Material & Lack of availability of proper tools & 3 & 2 & Moderate \\
\hline Source: Primary Data (2020).
\end{tabular}

The results of the analysis with a risk assessment of material factors showed that the lack of availability of the right tools was given a severity value of 3 and a likelihood value of 2 so that it was included in the moderate risk category.

\section{Environment factor risk assessment}

The following is a risk assessment analysis of environmental factors that have been obtained from the results of hazard identification. Risk assessment of environmental factors can be seen in Table 10.

Table 10: Risk assessment of environment factors

\begin{tabular}{lllll}
\hline Hazard & Risk & $\mathrm{S}$ & $\mathrm{L}$ & $\mathrm{R}$ \\
\hline Environment & Poor sanitation and water supply & 4 & 2 & High \\
& Lack of family support & 3 & 1 & $\begin{array}{l}\text { Moderate } \\
\text { The toilet is not hygienic }\end{array}$ \\
& 4 & 2 & \\
\hline Source: Primary Data (2020). & & & \\
\\
The results of the analysis with a risk
\end{tabular}

poor sanitation and water supply were given a severity score of 4 and a likelihood value of 2 so that they were included in the high-risk category. Poor family support is given a severity score of 3 and a likelihood value of 1 so that it is included in the moderate risk category. MCK is less hygienic given a severity value of 4 and a likelihood value of 2 so that it is included in the high-risk category.

The following is the final result of the analysis using HIRA; there are several risk categories, namely low risk of $13.3 \%$, moderate $40 \%$, high by $20 \%$, and extreme by $26.7 \%$. The following is a diagram of the total risk category from analysis using HIRA in Figure 3.

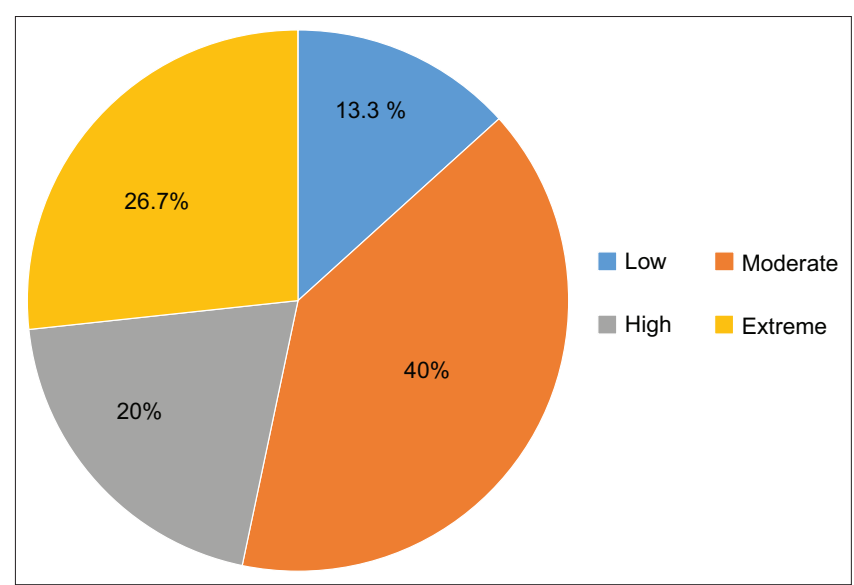

Figure 3: Risk Assessment of Stunting Prevalence Factors for Toddlers. Source: Primary Data (2020)

\section{Discussion}

Risk assessment of stunting prevalence factors for toddlers extreme risk category (26.7\%) is very at risk of increasing the incidence of stunting. Fulfilling nutritional needs during pregnancy, performing antenatal care, and measuring and monitoring the weight and length of a baby born regularly are very important for efforts to reduce the risk of stunting [17].

Furthermore, from this risk, several recommendations for improvements or suggestions can be made by related parties so that problems that occur can be resolved or minimized. The following are risk factors belonging to the extreme risk category.

1. Lack of application of Clean and Healthy Behavior (PHBS)

2. Low coverage of exclusive breastfeeding

3. Lack of infant nutrition

4. Low family economy.

Furthermore, from the 4 problems above, recommendations for improvement or suggestions for improvement are given by the researcher so that these things can be minimized and avoided so that the percentage of the prevalence of stunting under five in Indonesia can match the numbers that have been 
targeted by the government and by adjusting the related provisions or regulations in times of pandemic.

1. Conducting education related to how to behave in a clean and healthy life (PHBS). This counseling can be provided through the local government or volunteers who can deliver and assist in practicing PHBS. The following are some materials that can be conveyed when conducting counseling, especially during a pandemic

a. Eat nutritious food

People are encouraged to eat nutritious foods, especially foods that contain Vitamin $\mathrm{C}$ and Vitamin $\mathrm{E}$ which can increase endurance. Consuming sources of nutrients directly from food has a better value than taking vitamin supplements

b. Get regular exercise

Regular exercise can improve blood flow, nourish the body and increase immunity, thus preventing the entry of viruses into the human body. Sports that do not have to be sports that are done outside the home. During a pandemic, exercise can also be done at home

c. Wash your hands often

Washing your hands with soap and running water is a very important factor in killing viruses that stick to your hands. Washing hands for at least 20 seconds must be cultivated so that people are not susceptible to contracting and transmitting the virus. Using a hand sanitizer is also an alternative if there is no place to wash your hands or when you are outside the house

d. Avoid touching your face

Avoid touching the face, especially the mouth, nose, and eyes because the corona-19 virus can easily enter the body through these areas

e. Using a mask

Using a mask can prevent transmission, both we transmit and transmission from other people. Try to keep a mask on when talking to other people

f. Enough rest

Adequate sleep is approximately 7 to $8 \mathrm{~h}$ a day. This can increase the body's immunity so that the body is not susceptible to disease. Avoid staying up late at night

g. Cough and sneeze etiquette

Do not use your hands to cover your mouth when you cough or sneeze, but use a tissue, handkerchief, or cover your mouth with your forearm

h. Keep the environment clean

Keeping the environment clean at home is enough to mop the house at least 2 times a day. Cleaning and wiping frequently touched i. Avoid crowds and keep a safe distance According to research, the droplet splashes that come out of a person's mouth are an average of $1.8 \mathrm{~m}$ away, so that the community is advised to keep a distance from other people at least $2 \mathrm{~m}$. Avoid physical contact with other people because this can be a medium for transmitting the virus.

2. Add insight and knowledge related to exclusive breastfeedings, such as:

a. Performing early initiation of breastfeeding (IMD) shortly after delivery

b. Proper latch and breastfeed the baby every 2 to $3 \mathrm{~h}$ to stimulate good milk production

c. Consult a doctor if anything abnormal happens

d. Always compress the breasts using warm water and gently massage so that there are no clogged areas

e. Perform acupressure on the face area so that the mother can relax so that it can trigger the hormone oxytocin in producing breast milk

f. Make the baby feel comfortable and calm first before giving breast milk

3. Provide different types of food to gain weight and improve nutrition in children, namely:

a. Fruits and vegetables, such as avocado, banana, watermelon, papaya, apples, oranges, and others

b. Minerals and vitamins, such as spinach, lettuce, mustard greens, carrots, kale, and others

c. Carbohydrates, such as cereals, bread, pasta, potatoes, corn, and others

d. Milk and other processed products, such as yogurt, ice cream, mayonnaise, cheese, and others

e. Proteins, such as tofu, tempeh, red meat, fish, eggs, nuts, and others

f. Fats, such as soybeans, cheese, whole milk, coconut milk, margarine, and others.

Examples of portions that can be given are:

a. Breakfast menu (06.00-08.00)

1. Carbohydrates: White or brown rice

2. Animal or vegetable: Omelette

3. Vegetables: Stir fry green beans or long beans

4. Oil: Coconut oil

5. Snack at 10.00: Toast filled with cheese.

b. Lunch menu (12.00-13.00)

1. Carbohydrates: White or brown rice

2. Animal or vegetable protein: fried chicken and tempeh

3. Vegetables: Vegetable soup

4. Fruits: Oranges 


\begin{tabular}{ll}
\hline 5. & Snack at 16.00: Chocolate pudding. \\
c. & Dinner menu (18.00-19.00) \\
1. & Rice or carbohydrate substitutes: Macaroni \\
2. & Animal protein: Minced meat \\
3. & Fat: Milk and cheese \\
4. & Fruit: Oranges \\
5. & Snack at 21.00: UHT milk.
\end{tabular}

4. The low family economy will increase the risk of stunting. The results of this study are following research conducted by [18], which shows a relationship between family income and the prevalence of iron deficiency anemia, which in turn will increase the risk of stunting. Higher incomes for families can afford to buy foods that contain complete nutrition and are good for the intake of babies and children, so that babies and children who get complete food intake are less likely to experience micronutrient deficiencies, such as iron deficiency anemia. Furthermore, socioeconomic factors and low-income can affect the occurrence of diarrhea and respiratory infections, which in turn increase the risk of stunting. To overcome the low family economic factor, the government has implemented programs to help underprivileged families such as the IDT program, Raskin (Rice for the poor), Social Safety Net (JPS), and Farm Business Credit (KUT). The government should be able to empower its human resources and make some concept changes if it is deemed that this is still not running optimally. The government must also think about the treatment given because treatment for underprivileged families in urban areas is different from treatment for underprivileged families and those in rural areas. The government can carry out these programs starting from areas or cities that have the highest prevalence value of stunting babies in Indonesia. This is also a challenge for the government in reaching areas that are difficult to reach, either by empowering the community or volunteers to help make the program successful or the government who directly intervenes to run the program so that the program can be implemented on target. This supports the study of the investigation of community economic factors on the decline in stunting cases. An increase in state economic income by $11 \%$ affects preventing one-fifth of stunting events. The use of 17 countries' budgets can reduce the burden of risk of increasing stunting [19]. The impact of COVID-19 was the decline in the Indonesian economy which also resulted in many requests for goods that were not following the number of goods, and also an increase in unemployment due to layoffs, as well as a decline in the value of currencies of various countries. The government also prioritizes various public service sectors such as health, handwashing facilities with soap, and also food and financial resources [20], [21].

The COVID-19 pandemic is undermining nutrition across the world, particularly in low- and middle-income countries (LMICs). The worst consequences are borne by young children. Some of the strategies to respond to COVID-19 - including physical distancing, school closures, trade restrictions, and country lockdowns - are impacting food systems by disrupting the production, transportation, and sale of nutritious, fresh, and affordable foods, forcing millions of families to rely on nutrient-poor alternatives. Based on a study by Fore et al. (2020) and Roberton et al. (2020), malnutrition could exacerbate the effects of COVID-19 in mothers and children. At the same time, more children are becoming malnourished due to the deteriorating quality of their diets, interruptions in nutrition and other essential services, and the socioeconomic shocks created by the pandemic in LMICs. Efforts to prevent the environment are very important in controlling the high incidence of stunting by increasing the supply of clean water, improving personal hygiene and the environment around the house, washing hands with soap, and providing milk and additional food [22]

The weakness of family support in recognizing and identifying stunting symptoms in children is also a risk factor in stunting incidents. This is indicated by the results of the study showing lack of family support as an indicator in the risk assessment of environment factors. According to research conducted by Black et al. (2013), maternal and child nutrition status plays an important role in infant morbidity, early development, and even long-term health; childhood stunting is the foundational cause of poor cognition, low adult wages, and lost productivity later in life. Timely and adequate complementary nutrition management is required for infants aged 6 months and over; exclusive breastfeeding is not sufficient to meet the nutritional needs of the child [23]. The incidence of stunting is a public health problem. Several factors related to stunting are delays in breastfeeding, lack of postnatal care and education, and respiratory tract infections, so that postnatal care and control and prevention of infection are needed so that it can threaten the quality of life in childhood [6], [24]. A basic understanding of health for the community and early identification of stunting in children and nutrition improvement is the main state political policy in achieving the Sustainable Development Goals targets [22], [25].

\section{Conclusion}

This research was conducted with the background of the high prevalence of stunting under five in Indonesia. Researchers used fishbone diagram analysis about the $5 \mathrm{~W}$ and $1 \mathrm{E}$ factors to obtain the 
factors causing the prevalence of stunting under five. After obtaining these factors, an analysis was carried out using hazard identification and a risk assessment to obtain the value and category of each risk that arose from low, moderate, high, and extreme risks. Research recommendations are given based on extreme risk categories, namely lack of PHBS application, low coverage of exclusive breastfeeding, lack of infant nutrition, and low family economy, so that the authors provide recommendations for improvements by the problems that have been found.

The recommendations for improvement given can be used by the government and those in need so that the implementation of the recommendations for improvement is expected to reduce the prevalence of stunting under five in Indonesia and can assist the government in achieving the target percentage for reducing the prevalence of children under five in Indonesia.

\section{References}

1. (TNP2K) TNPPK. Strategi Nasional Percepatan Pencegahan Stunting 2018-2024 (National Strategy for Accelerating Stunting Prevention 2018-2024). Tim Nas Percepatan Penanggulangan Kemiskin Sekr Wakil Pres Republik Indones, November; 2018. p. 1-32.

2. Lawaceng C, Rahayu AY. Tantangan pencegahan stunting pada era adaptasi baru "new normal" melalui pemberdayaan masyarakat di kabupaten pandeglang. J Kebijak Kesehat Indones. 2020;9(3):136-46. https://doi.org/10.22146/jkki.57781

3. McGuire S; World Health Organization. Comprehensive Implementation Plan on Maternal, Infant, and Young Child Nutrition. Geneva, Switzerland: World Health Organization; 2014.

4. De Onis $M$, Blosser M, Organization WH. WHO Global Database on Child Growth and Malnutrition. Geneva: World Health Organization; 1997.

5. Martorell R, Young MF. Patterns of stunting and wasting: potential explanatory factors. Adv Nutr. 2012;3(2):227-33.

6. Berhanu G, Mekonnen S, Sisay M. Prevalence of stunting and associated factors among preschool children: A communitybased comparative cross-sectional study in Ethiopia. BMC Nutr. 2018;4(1):1-15

7. Akseer N, Kandru G, Keats EC, Bhutta ZA. COVID-19 pandemic and mitigation strategies: Implications for maternal and child health and nutrition. Am J Clin Nutr. 2020;112(2):251-6. https:// doi.org/10.1093/ajcn/nqaa171

PMid:32559276

8. World Health Organization. Naming the Coronavirus Disease (COVID-19) and the Virus that Causes it. Geneva: World Health Organization; 2020.

9. Fore $\mathrm{HH}$, Dongyu $\mathrm{Q}$, Beasley DM, Ghebreyesus TA. Child malnutrition and COVID-19: The time to act is now. Lancet. 2020;396(10250):517-8. https://doi.org/10.1016/ S0140-6736(20)31648-2

10. Building Resilience for Peace and Food Security. The State of Food Security and Nutrition in the World. Rome: Building Resilience for Peace and Food Security. 2017.
11. Picanyol C. Is there a better way to Track Nutrition Spending?; 2014.

12. Black RE, Victora CG, Walker SP, Bhutta ZA, Christian P, De Onis M, et al. Maternal and child undernutrition and overweight in lowincome and middle-income countries. Lancet. 2013;382(9890):42751. https://doi.org/10.1016/S0140-6736(13)60937-X PMid:23746772

13. Langley-Evans SC. Fetal Nutrition and Adult Disease: Programming of Chronic Disease through Fetal Exposure to Undernutrition. Wallingford, United Kingdom: Centre for Agriculture and Bioscience International; 2004.

14. Roberton T, Carter ED, Chou VB, Stegmuller AR, Jackson BD, Tam $Y$, et al. Early estimates of the indirect effects of the COVID-19 pandemic on maternal and child mortality in lowincome and middle-income countries: A modeling study. Lancet Glob Health. 2020;8(7):e901-8.

15. Sholihah Q. Pengantar Metodologi Penelitian. Indonesia: Universitas Brawijaya Press; 2020.

16. Standards Australia International. Handbook: Risk Management Guidelines, Companion to as/nzs 4360. Sydney: Standards Australia International Ltd.; 2004.

17. Hadisuyitno J, Riyadi BD. Determinant factors of stunting events of toddlers in Batu city Indonesia. Syst Rev Pharm. 2021;12(1):231-4.

18. Wahtini S. Faktor-faktor yang berpengaruh dengan kejadian anemia pada bayi. JHeS J Health Stud. 2019;3(1):21-7.

19. Hoddinott J, Alderman H, Behrman JR, Haddad L, Horton S. The economic rationale for investing in stunting reduction. Matern Child Nutr. 2013;9(S2):69-82. https://doi.org/10.1111/ mcn.12080

PMid:24074319

20. Haryono BS, Sholihah Q, Hidayati F, Ahmadi B, Lenggono KA Doctoral $\mathrm{S}$, et al. The role of politics and policy strategy in facing a Covid-19 pandemic: Case study in Indonesia. 2021;11:3833-9.

21. Lenggono KA, Sholihah Q, Djati MS, Putranto N, Tangkas $T$, Hastuti AP, et al. Quality audit analysis of the implementation of handwashing 5 moments 6 steps for doctors and nurses with the incidence of phlebitis in the hospital. Syst Rev Pharm. 2020;11(1):268-72. PMid:32730742

22. Mbuya MN, Humphrey $\mathrm{JH}$. Preventing environmental enteric dysfunction through improved water, sanitation, and hygiene: An opportunity for stunting reduction in developing countries. Matern Child Nutr. 2016;12(Suppl 1):106-20. https://doi. org/10.1111/mcn.12220 PMid:26542185

23. Ban L, Guo S, Scherpbier RW, Wang X, Zhou H, Tata LJ Child feeding and stunting prevalence in left-behind children: A descriptive analysis of data from a central and western Chinese population. Int J Public Health. 2017;62(1):143-51. PMid:27318527

24. Connery AK, Lamb MM, Colbert AM, Bauer D, Hernández S, Arroyave $\mathrm{P}$, et al. Parent report of health-related quality of life in young children in rural guatemala: Implementation, reliability, and validity of the PedsQL in stunting and wasting. Glob Pediatr Health. 2021;8:21991028. https://doi. org/10.1177/2333794X21991028

PMid:33614851

25. Gonete AT, Kassahun B, Mekonnen EG, Takele WW. Stunting at birth and associated factors among newborns delivered at the University of Gondar Comprehensive Specialized Referral Hospital. PLoS One. 2021;16(1):1-16. https://doi.org/10.1371/ journal.pone. 0245528

PMid:33471862 